\title{
Climate change and plant pathogen biodiversity: The case of witches' broom outbreak on Vachellia xanthophloea (Benth.) Banfi \& Galasso) in Botswana
}

\author{
E. B. Khonga \\ Department of Crop and Soil Sciences, Botswana University of Agriculture and Natural Resources, Gaborone, Botswana
}

\section{ARTICLE INFORMATION}

\section{Keywords}

Climate change

Pathogen biodiversity

Vachellia xanthophloea,

Witches' broom

Ravenelia natalensis

Botswana

\section{Article History:}

Submission date: 01 Aug. 2018

Revised: $\quad 02$ Jun. 2019

Accepted: $\quad 12$ Jun. 2019

Available online: 24 Sept. 2019

https://bojaas.buan.ac.bw

\section{Corresponding Author:}

Elenimo B. Khonga
畕 : (+267) 36500206
: (+267) 3928753
: ebkhonga@ buan.ac.bw

\begin{abstract}
Climate change, typified by drought, floods and rising temperatures continue to affect biodiversity in the world. Recently, outbreaks of new insect, weed and plant pathogen species have been reported in SADC and some old ones have increased in severity while others have diminished. Examples of new insects that have threated food security and trade in the region include the fall army worm (Spodoptera frugiperda) and tomato leaf miner (Tuta absoluta). Over $50 \%$ of the Hartbeespoort Dam near Pretoria is covered by water hyacinth (Eichhornia crassipes) reducing property values and tourism in the area. In August 2014, witches' broom outbreak on fever tree was first observed in Gaborone. Microscopic examination of disease signs revealed, urediospores, teliospores, aeciospores and aecia typical of Ravenelia sp. Samples were sent to the FABI, University of Pretoria where the pathogen was tentatively identified as $R$. natalensis or $R$. hieronymi. After the 2014/2015 and 2015/16 poor rain seasons few new infections were recorded in August. Following the heavy rains caused by cyclone Dineo, the epiphytotic exploded starting July 2018 and almost all fever trees in the major towns of Botswana were attacked. The witches' brooms were also infected by powdery mildew (Erysiphe sp.) and Diplodia sp. which caused black twig dieback. The fever tree natural distribution is limited to the Tuli block but it has been introduced south as a landscape and shade tree. The tree is now invasive spreading rapidly along drainage channels and rivers around Gaborone. Currently the pathogen may be a threat to other Vachellia and Senegalia spp. in Botswana. The witches' brooms are releasing trillions of spores into the air which may result in new human allergies. The implications of the outbreak on tree biodiversity and how the disease can be managed should be investigated.
\end{abstract}

\section{Introduction}

Global climate changes in response to changes in the cryosphere, hydrosphere, biosphere and other atmospheric and interacting factors have affected life on planet earth for millions of years. However, human activities which emit greenhouse gases are now increasingly influencing more rapid changes in global climate (Chakraborty and Newton 2011). According to an article in The New York Times of 17th December 2017 authored by Brad Plummer and Nadja Popovich, global warming fueled five extreme weather events, namely record high temperatures around the world, coral bleaching in the Great Barrier Reef, drought in Africa (especially southern Africa), wild fires in North America and the warm "blob" in the Pacific Ocean which resulted in toxic algal blooms that killed sea birds (https://www.nytimes.com/2017/12/14/climate/clima te-extreme-weather-attribution.html). In the Southern Africa Development Community (SADC) Region extreme weather events like floods, droughts and rising temperatures are negatively affecting biodiversity, food security, human health and regional trade. For example the 2015/16 cropping season was the driest in 35 years and a regional 
drought disaster was declared in July 2016 by SADC because 40 million people were food insecure and 643000 cattle died (https://www.sadc.int/newsevents/newsletters/sadc-regional-situation-update-elnino-induced-drought/). However, the 2017 cropping season was very wet following cyclone Dineo so that some countries like South Africa had record high maize yields while others had no yields due to floods. On a positive side for Botswana, the Gaborone dam which was totally dry due to lack of in-flow for over five years filled to capacity within three days as a result of the cyclone.

Recent outbreaks of new pests and diseases as well as upsurges or disappearance of old pests and diseases could be attributed to extreme weather events among other factors such as growth in international trade and travel, pesticide resistance and reduced or poor phytosanitary control measures (Willis, 2017). Few examples of pest and disease outbreaks in SADC will be cited in addition to the outbreak of fever tree witches' broom in Botswana.

\section{Fall army worm (Spodoptera frugiperda Smith, 1797)}

During the 2016/2017 cropping season the fall armyworm outbreak made news headlines in many countries in Africa and in SADC region the outbreak spelt doom for millions of people who rely on maize as a staple (Ratolojanahary, 2017). The moth Spodoptera frugiperda which is endemic to North and South America, was first reported in Nigeria, Togo and Sao Tome and Principe in 2016 and by April 2017 the pest was reported in most SADC countries. It is not yet known how the moth was introduced in Africa. The fall armyworm attacks plants in the grass family such as maize, rice, sugarcane, sorghum and millet. In maize the pest is serious because the larvae feed from within the growing point and the developing cobs making chemical control with contact pesticides ineffective. Will the fall armyworm replace the endemic African armyworm (S. exempta) in the long run? The adult moth has been reported to fly distances of up to $1600 \mathrm{~km}$. If $2017 / 2018$ rain season is dry, will the fall armyworm increase or decrease? The economic losses of the outbreak in SADC were estimated at $\$ 13.38$ billion and for maize alone it was $\$ 3.06$ billion.

\section{Tomato leaf miner (Tuta absoluta)}

Outbreak of Tuta absoluta the tomato leaf miner (TLM) in 2016/2017 cropping season in Nigeria, South Africa and other SADC countries had devastating effects on tomato trade and consumer prices for tomatoes. In Nigeria $80 \%$ of the tomato farms were attacked resulting in a $400 \%$ increase in the price of tomatoes and some states declared a state of emergency (https://afkinsider.com/134604/badnews-tough-year-south-africa-tomato-leaf-miner outbreak-reported//). The pest is believed to have hitched a ride form South America, where it is endemic, to Europe, Asia and finally Africa. In Botswana importation of tomatoes was banned for a while to enable the Ministry of Agricultural Development and Food Security to contain the pest outbreak. Tuta absoluta is a moth which lays eggs on host plants and upon hatching the young larvae burrow through leaves, stems and fruits of tomato and other solanaceous plants such as peppers, eggplants and tobacco.

\section{Water hyacinth (Eichhornia crassipes)}

Water hyacinth is an old aquatic invasive plant which has been causing serious problems in many parts of the world. However with rising water temperatures and eutrophication in many water reservoirs the weed seems to be exploding. In South Africa, the weed made the news headlines because of its explosion in Hartbeespoort Dam where over $40 \%$ of the water surface (Fig. 1) is now covered by the weed seriously affecting tourism and property values of the resort town of Hartbeespoort (https://www.environment.co.za/weeds-invadersalien-vegetation/water-hyacinth-crisis-harties.html).

One of the reasons for the explosion is that a mechanical barrier at the Magalies river bridge which kept the weed upstream of the dam broke down during flooding of the river allowing the mass of the weed to float into the river. The heavy rains and raw sewage loaded the dam with nitrates and phosphates resulting in the population explosion.

\section{Witches' broom outbreak on Vachellia xanthophloea in Botswana}

Vachellia xanthophloea (Benth.) Banfi \& Galasso commonly known as fever tree is an African indigenous tree in the Fabaceae family. It is naturally distributed along the eastern side of Africa from Somalia through Kenya, Tanzania, Malawi, Mozambique, Zimbabwe, Zambia, Botswana, South Africa and Swaziland. The tree grows near swamps, riverine forests or at lakesides or areas with high ground water table and is able to tolerate several degrees of frost (Orwa et al 2009). In Botswana natural stands are limited to the Tuli Block in Ntani game reserve (Setshogo and Venter 2003). The English common name fever tree or yellow fever tree is as a result of its presence in malaria infested areas and it was believed to have a cure for malaria. Other local names include: English (sulphur bark and Naivasha thorn tree); Setswana (more o mosetlha), Afrikaans (koorsboom) and Chichewa (nseta nyani: literally meaning "the one that cleans the baboon's ass after defecation"). 
The tree has many uses. In the wild it provides food for wild animals such as elephants, giraffes and monkeys. The flowers provide pollen for bees and livestock browse on the leaves and pods. The bark and roots are valued for their medicinal properties and are used by traditional doctors to treat various diseases including fever (Botha et al., 2002; Palgrave

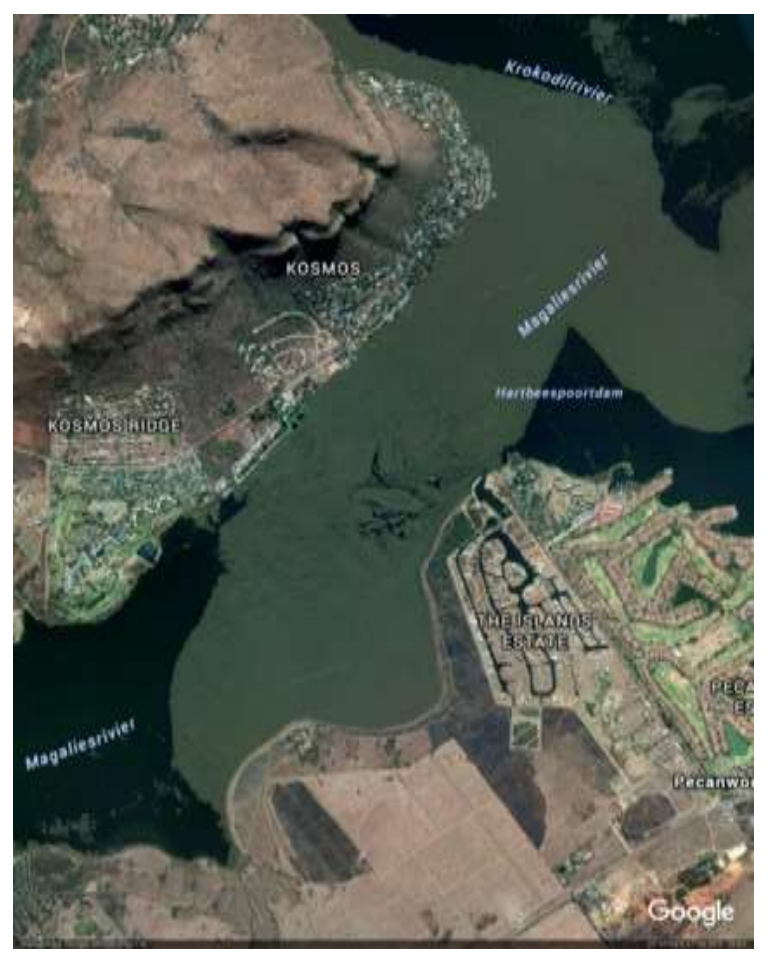

Fig. 1: Water hyacinth infestation of Hartbeespoort Dam (Source: Google Earth).

2002; Lemmens, 2006). Mature trees produce a general purpose timber that is used in construction, boat building and furniture (Van Wyk, 2001; Botha et al., 2002; Lemmens, 2006). The wood requires seasoning before use because it is liable to cracking (Palgrave, 2002).

In Botswana and South Africa fever tree has been introduced outside its range as a landscape and shade tree in urban centres such as Gaborone, Francistown, Johannesburg and as far south as Cape Town. The tree is popular as a shade and ornamental tree in car parks at shopping malls, hospitals and office complexes and along some roads. The price for the tree seedlings is about BWP300 at the nursery centers in Gaborone. However the tree is rapidly spreading into places where it was not originally planted such as along water drainage channels and is displaying tendencies of being invasive.

\section{Description of witches' broom disease}

Witches' broom is a broom-like growth or massed proliferation due to dense clustering of branches of woody plants (Agrios, 2005). In non-woody plants such as cereals the disease is called crazy top. The affected part looks like a broom and in trees witches' brooms are mistaken for birds' nests. Similar branching in roots is called fasciation. Physiologically, witches' brooms are mainly caused by interference with plant growth hormones such as auxins, cytokinins and giberrelins. Both biotic and abiotic factors can cause witches' brooms but bacteria and fungi are the most common causes of witches' brooms. The pathogens can cause imbalances of hormones by producing and stimulating or inhibiting production by the host plant. Most witches' brooms tend to have branches in prolonged juvenile state to favour the growth of the pathogen (Agrios, 2005) most of which are biotrophs which require a living cell to survive.

\section{Methodology}

From August 2014 symptoms of greenish overgrowths on fever tree twigs were first noticed on fever trees in Phakalane, the University of Botswana, Botswana National Productivity Centre and Fairgrounds in Gaborone. The overgrowth turned brown with time and by September to October 2014 most of the overgrowths were brownish in colour.

Samples of affected parts were collected in plastic bags and examined in the Plant Pathology Laboratory at the Botswana University of Agriculture and Natural Resources (BUAN). Symptoms were described and disease signs were observed using a Nikon SMZ800 with a NK DS Fi1 camera dissecting and Lieca DM 500 compound microscopes. A pressed disease specimen was sent to Dr. Alistair McTaggart, a Post-Doctoral Researcher at the Forestry and Agricultural Biotechnology Institute (FABI), University of Pretoria, South Africa for confirmation of pathogen identity. Morphological characteristics recorded included size, shape and colour of spores and spore bearing structures. Number of spores produced per witches' broom were estimated by using Neubuaer haemocytometer slide after spores from one fruit bearing structure called aecium was crushed into $1 \mathrm{~mL}$ of water.

\section{Results and Discussion}

\section{Symptom description}

Small green branches that were curved and soft were formed at the tip of a twig or lateral bud. The small branches further branched forming typical witches' brooms which varied in length and width (Fig. 2).

The small branches later turned brown with rough surfaces following the rupture of fungal structures through the epidermis of the stems. 


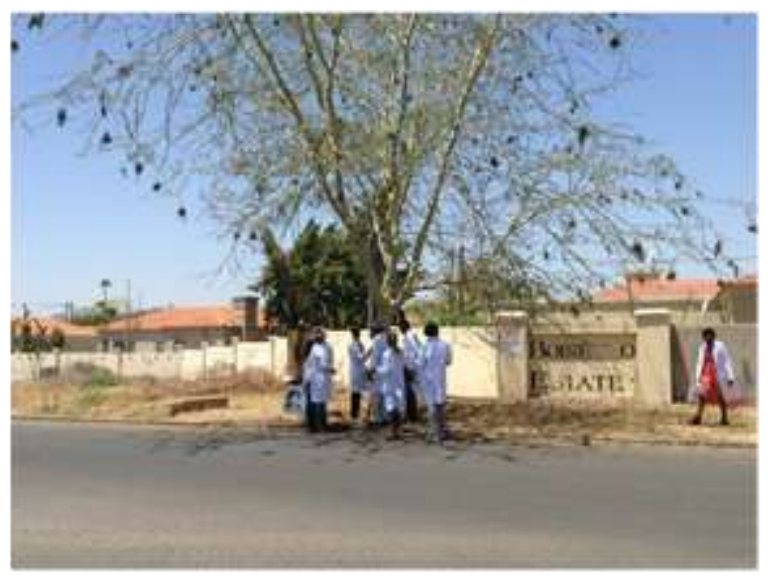

(a)

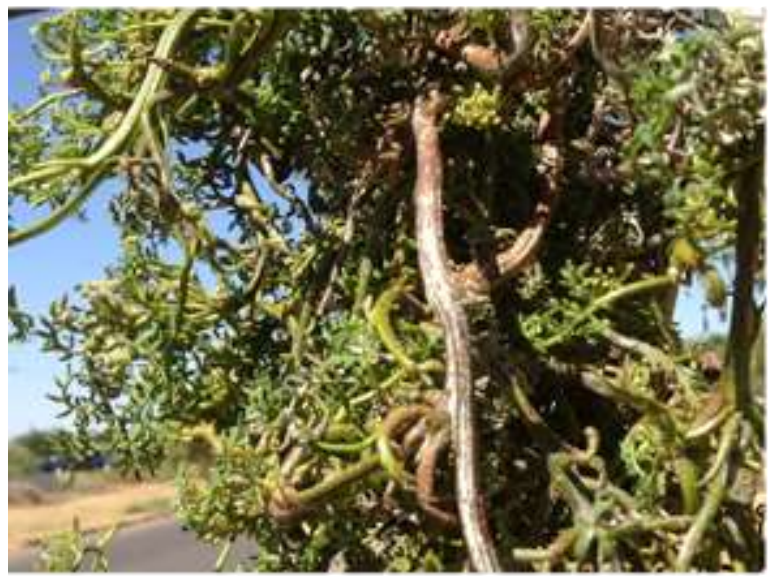

(c)

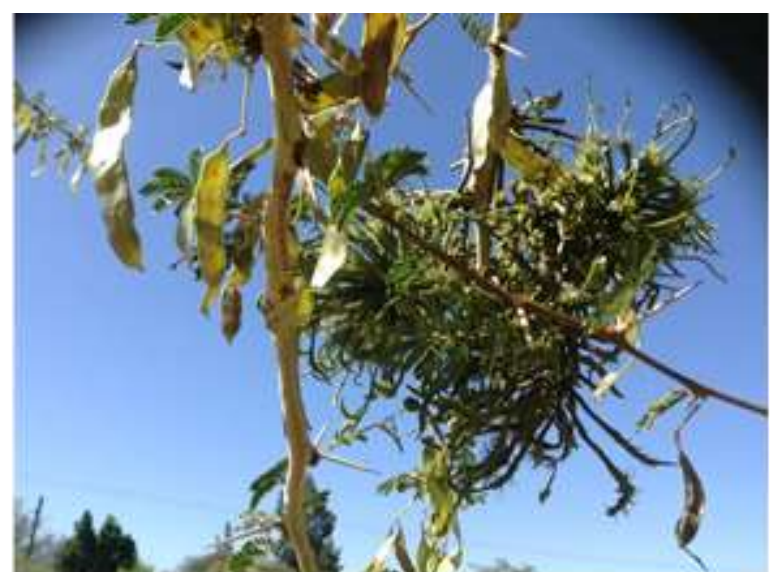

(b)

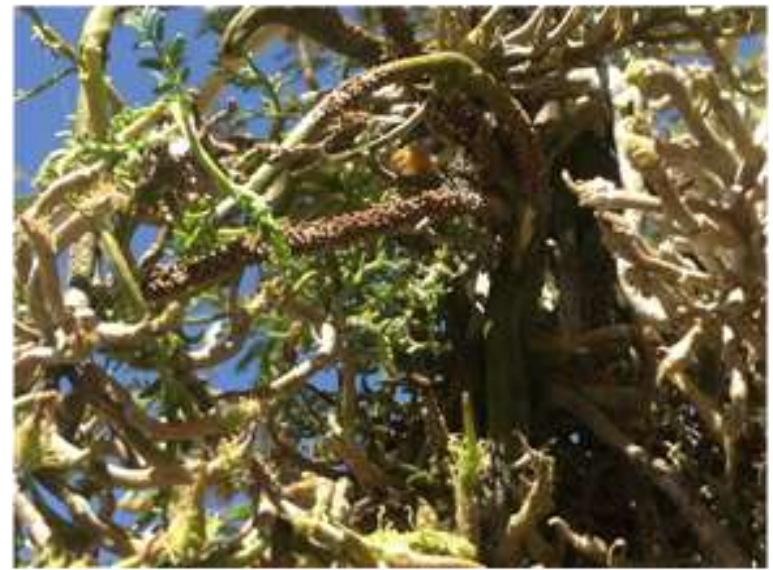

(d)

Fig. 2: Symptoms of witches' broom on fever tree (a) infected tree in Phakalane, (b) young witches' broom, (c) extensive branching of the twig and (d) close up showing brown aecia on twigs.

The branches continued to grow first green and later turning brown. However during dry spells in December 2014 and January 2015, the witches' brooms stopped growing and dried up. The witches' brooms remained attached to the twigs but slowly they broke up in strong winds and some fell off the trees.

The 2015/2016 rain season was one of the driest on record and by August 2016, no or very few new witches' brooms were observed and most of the trees infected in previous season looked clean. However, the 2016/2017 rain season was very wet including cyclone Dineo and the outbreak of symptoms in August 2017 was observed on almost every fever tree in Gaborone. The size of the witches' brooms were generally large and the numbers per tree were up to 200 or more for large trees. This observation suggests that disease epidemic onset is favoured by high rainfall seasons.

\section{Description of disease signs}

The pathogen formed spore-bearing cylindrical tubes (aecia) on twigs measuring about $2 \mathrm{~mm}$ high and 0.5 $\mathrm{mm}$ in diameter (Fig. 2) and light brown to gray in colour. The aecial wall or peridium was a cell thick and the peridial cells were 5-sided, irregular and striate-verrucose. The pathogen also formed roundish erumpent structures (telia) dark brown to black in colour (Fig. 3). The aeciospores had varied shapes and sizes ranging from spherical to ovoid or oblongellipsoid and pale yellow or pale golden in colour. The size ranged from 20-26 $\mu \mathrm{m}$ long and 20-22 $\mu \mathrm{m}$ in diameter (Fig. 4). Spores (teliospores) formed in the telia were multi-celled, 72-86 $\mu \mathrm{m}$ in diameter, clear dark golden-brown, smooth, variable in shape, flat or often concave on the underside, strongly convex on the upper side (Fig. 5).

\section{Tentative diagnosis of the pathogen}

The tentative disease diagnosis based on symptoms and morphological characteristics of the fungal 

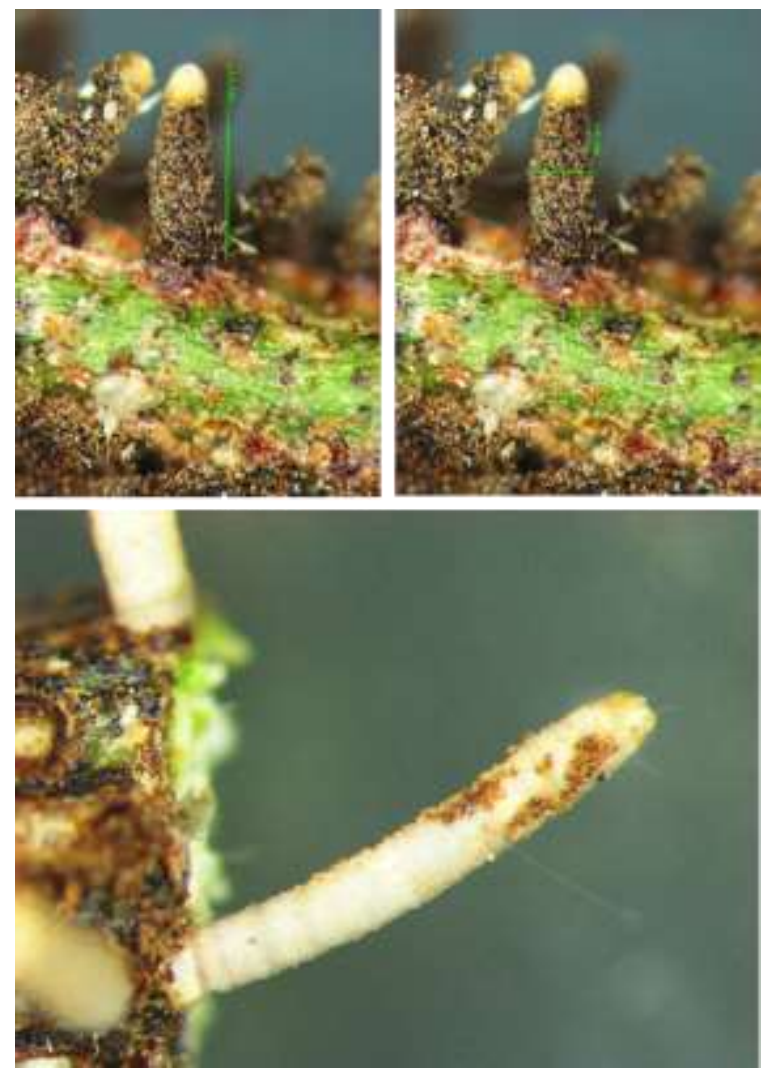

Fig. 3: Aecia observed under a dissecting microscope.

pathogen (aecia, telia, aeciospores and teliospores) is witches' broom caused by $R$ natalensis Syd. P. Syd \& Pole-Evans. Ravenelia natalensis was first reported in 2006 from a nursery of $V$. xanthophloea in Botswana by Wood (2006) as reported by McTaggart et al - Rust Fungi of Southern Africa (http://collections.daff.qld.gov.au/web/key/africarust/ Media/Html/rusts.html). Conclusive diagnosis depends on molecular characterization of the pathogen. The morphological characteristics observed are also similar to those of $R$. hieronymi described by Hernandez and Hennen (2009) on Vachellia caven (Rome cassie) and V. farnesiana (sweet acacia). The disease is reported on $V$. caven in Brazil, Chile, Paraguay and Uruguay and on $V$. farnesiana in Brazil, Chile and Uruguay in South America. Literature on fever tree witches' broom caused by $R$. hieronymi in Africa is rather scanty. The author observed witches' brooms on a natural stand of $V$. xanthophloea near Lake Malawi in Mangochi in December 2016 (Fig. 6).

\section{Impact of the disease on plant and pathogen biodiversity}

Since the outbreak of the disease in 2014, the overall health and aesthetics of fever trees has been negatively impacted in that the shapes of the trees are changing as the heavy witches' brooms cause twigs
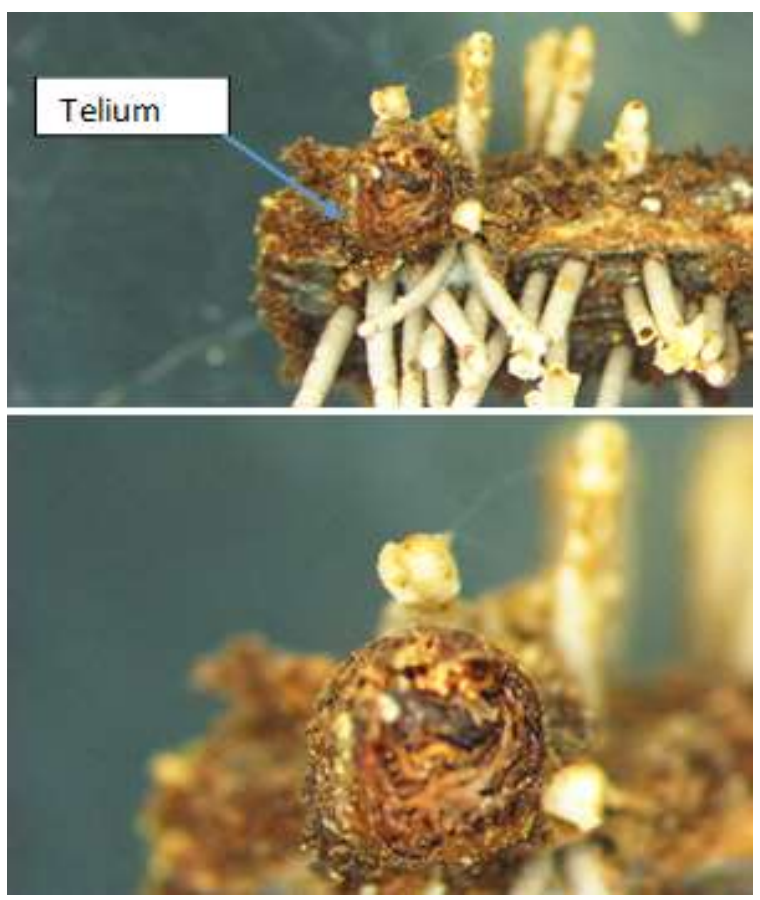

Fig. 4: Telium bearing teliospores among the aecia.

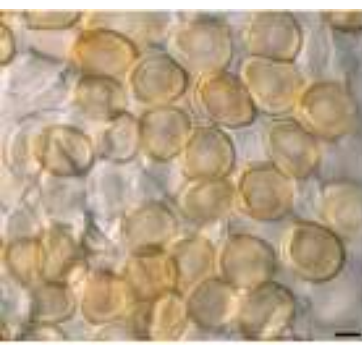

(a)

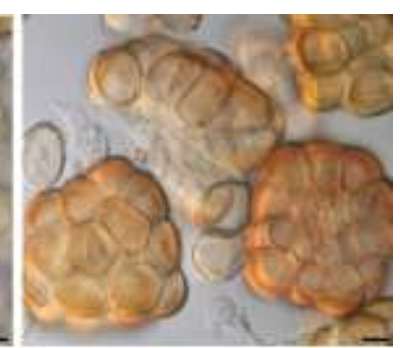

(b)

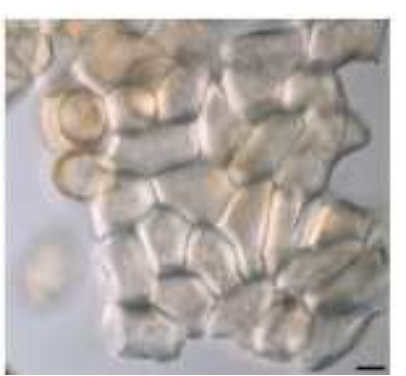

(c)
Fig. 5: Spores associated with witches' broom twigs (a) aeciospores and (b) teleospores and (c) cells of peridum (scale bar: $10 \mu \mathrm{m}$, Courtesy Dr. Alistair McTaggart, FABI, University of Pretoria).

to bend. Trees planted in car parks and office complexes are unsightly because of the brownish colour of the brooms. Over time the trees will be weakened as brooms act as sinks for photosynthates and other nutrients for the rust fungus thus starving other parts of the tree. The witches' brooms create microclimates for other diseases to develop. During 

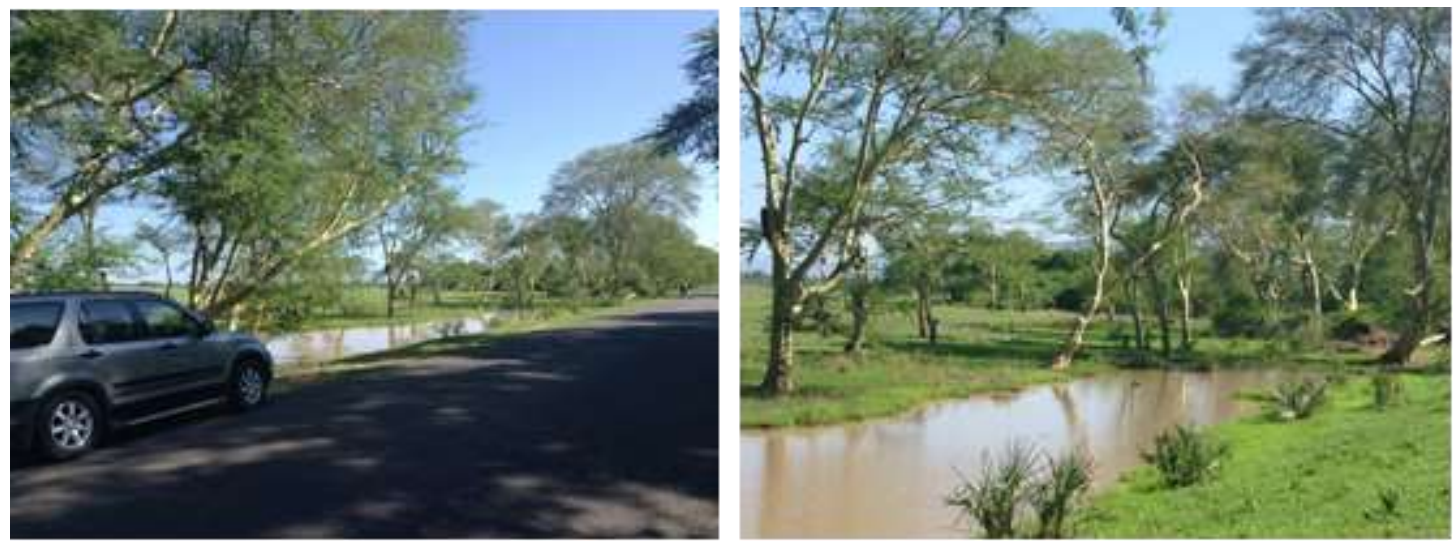

Fig. 6: Natural stand of V xanthophloea with witches' broom near Lake Malawi, Mangochi, Malawi.

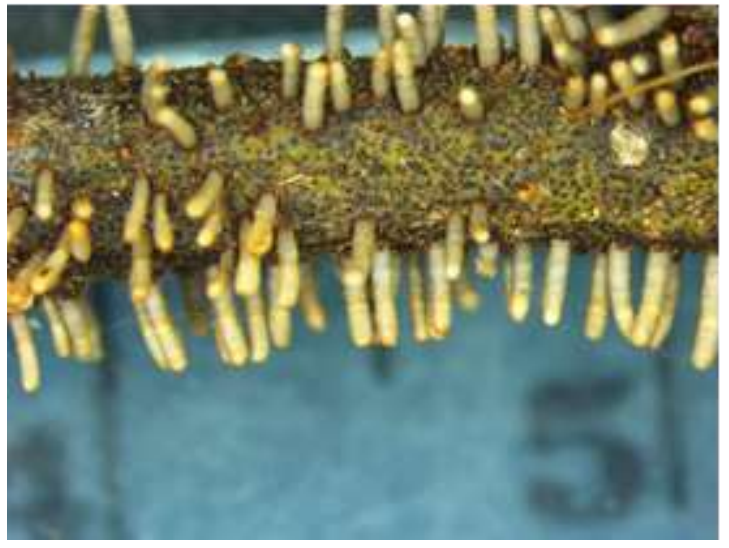

(a)

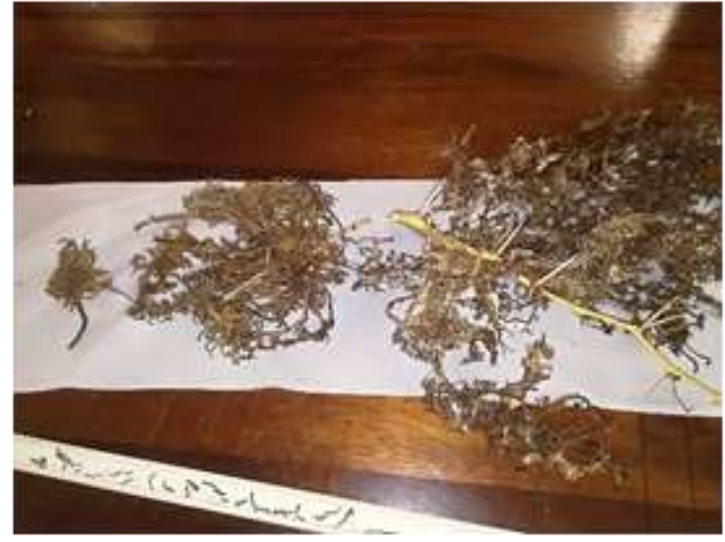

(b)

Fig. 7: (a) Number of eacia per $10 \mathrm{~mm}$ length and (b) sizes of witches' brooms used in estimating number of spores released into the air.

the 2016/2017 outbreak, some of the witches' brooms were heavily attacked by powdery mildew thus further demanding nutrients from the host tree and white mycophagous mites and mealy bugs were also observed.

The mycoflora and fauna associated with the witches' brooms should be an area of further work. Currently, the disease outbreak is limited to fever tree but there is a potential threat of the pathogen attacking other Vachellia and Senegalia species in Botswana. In Northern Namibia Ravenelia acaciaenigrescentis has been recorded on Acacia nigrescens (Senegalia nigrescens).

\section{Impact of the disease on human health}

Ravenelia natalensis is an efficient producer of spores which are released into the air thus contributing to human allergens in the air. The average number of aeciospores per aecium were estimated to be 32,375 . The average number of aecia per $10 \mathrm{~mm}$ length of witches' broom twig was 52 .
The average total number of branches of a very small twig (Fig 6) was 60 and the twigs when placed endto-end had a total length $1300 \mathrm{~mm}$.

The estimated total number of spores produced by one small witches' broom was: $52 \mathrm{aecia} / \mathrm{cm}$ $\mathrm{x} 130 \mathrm{~cm} \times 32,375$ spores/aecium $=2.18855 \times 10^{8}$. A large witches' broom 20 times the size of the small ones was estimates to produce $4.223771 \times 10^{9}$. An average large tree could have up to 200 or more witches' brooms thus contributing $8.447542 \times 10^{11}$ spores. The outbreak of the disease has drastically affected the spore composition of the air in homes and areas with the affected trees.

There is a possibility that some people are developing allergic reactions to these spores resulting in increased incidences of respiratory challenges especially in children. This is another area which need investigation. Management of foliar diseases of standing trees in the wild is usually not economical and not easy to carry out. In most cases natural enemies or biocontrol agents tend to bring down the 
disease outbreaks unless the disease is newly introduced into an area. In this case, natural enemies from the centre of origin of the pathogen have to be introduced to manage the disease. In the nursery tree diseases are managed mainly by protection using protectant and systemic fungicides spread routinely or a on a need basis.

Currently there are no registered fungicides for control of witches' broom disease in the nursery, hence the need for research to screen fungicides for control of the disease in the nursery and screening for resistance. In mature plants most home owners have resorted to pruning the lower infected branches but the top parts cannot be reached and others are just cutting the trees down.

\section{Conclusion}

Climate change will continue to affect biodiversity by favouring some species to explode and dominate and others to decline. In agriculture, there is need to have early warning systems in place to cover monitoring and reporting of new species of pests and pathogens. This requires annual scouting for unusual disease symptoms, insect infestations, weed and other invasive species. Witches' broom of Vachellia xanthophoea caused by Ravenelia natalensis or $R$. hieronymi has been established in Botswana and measures of control should be developed. The spores of the pathogen may pose a serious health hazard to children and other immune-compromised individuals resulting in respiratory challenges especially if trees are in the vicinity of hospitals and homes where spores can be concentrated in rooms close to the tree. Research on control of the disease and potential health hazard associated with high spore numbers of the pathogen in enclosed places close to the trees should be carried out.

\section{References}

Agrios (2005). Plant pathology $5^{\text {th }}$ ed. Elsevier Academic Press.

Ritschel A., Berndt, R and Oberwinkler, F., (2007). New observations of rust fungi (Uredinales) from northern Namibia. Mycological Progress. 6:137-150.

Botha J., Witkowski E.T.F. and Shackleton C.M. (2002). A comparison of anthropogenic and elephant disturbance on Acacia xanthophloea (fever tree) populations in the Lowveld, South Africa. Koedoe 45(1): 9-18.

Chakraborty S. and Newton A.C. (2011). Climate change, plant diseases and food security: an overview. Plant Pathology 60(1).2-14.

Hernandez J.R., and Hennen J.F. (2009). Rust fungi causing galls, witches' brooms, and other abnormal plant growths in northwestern Argentina. Mycologia 95(4), 2003, pp. 728-755.

Lemmens R.H.M.J. (2006). Acacia xanthophloea. In: D. Louppe, A.A Oteng-Amoako and M. Brink (Eds).
Prota 7(1): Timbers/Bois d'oeuvre 1. [CD-ROM]. PROTA, Wageningen, Netherlands

Orwa C., Mutua A., Kindt R., Jamnadass R. and Anthony S. (2009). Agroforestry Database: A Tree Reference and Selection Guide Version 4.0. World Agroforestry Centre, Kenya. http://www.worldagroforestry.org/sites/treedbs/treedat abases.asp

Palgrave K.C. (2002). Trees of southern Africa. $3^{\text {rd }}$ Edition revised and updated by M.C. Palgrave. Struik Publishers. 1212pp.

Ratolojanahary M. (2017). Fall armyworm outbreak in the SADC region: How to respond? www.shininginstitute.com/blog/2017/6/9/fallarmyworm-outbreaks-in-the-SADC-region-how-torespond\#

Setshogo M.P. and Venter F. (2003). Trees of Botswana: names and distribution SABONET Report No. 18 Southern African Botanical Diversity Network, Pretoria Page 66.

Van Wyk P. (2001). Trees of southern Africa. Struik Nature, Cape Town. In: K.J. Willis, (Ed), 2017. State of the World's Plants 2017. Report. Royal Botanic Gardens, Kew, 144pp ISBN: 978-1-84246-647-6

Wood A.R. (2006). New and interesting records of southern African rust fungi (Uredinales). South African Journal of Botany 72: 534-543. 